\title{
Government Expenditure and Inflation in Nigeria
}

\author{
Chioma Chidinma George-Anokwuru ${ }^{1} \&$ Bosco Itoro Ekpenyong ${ }^{1}$ \\ ${ }^{1}$ Economics Department, Faculty of Social Sciences, University of Port Harcourt, Rivers State, Nigeria \\ Correspondence: Chioma Chidinma George-Anokwuru, Economics Department, Faculty of Social Sciences, \\ University of Port Harcourt, Rivers State, Nigeria. E-mail: chiomanwoga@yahoo.com, bosco3m@gmail.com
}

Received: May 12, 2020; Accepted: June 3, 2020; Published: June 3, 2020

\begin{abstract}
The impact of government spending on Nigeria's inflation levels between 1999 and 2019 was x-rayed in this paper. The data for the study were sourced from CBN statistical bulletin and Autoregressive Distributed Lag model was used as the main analytical tool.

A long-run relationship among this study's variables was realized, using the ARDL Bounds test. The result also revealed a positive but insignificant relationship between government expenditure and inflation rate in the shortrun. Moreover, in the long-run, government expenditure has negative and is statistically significant inflation rate. Money supply has a negative and is statistically insignificant with inflation rate in the short-run. In the long-run, money supply has a positive and significant relationship with inflation rate. Gross domestic product was negatively related to inflation rate in both short-run and long-run. Moreover, exchange rate affected inflation rate negatively and significantly in the short-run and positively and significantly in the long-run. The increasing demands of the population affected inflation rate positively and significantly in both short-run and long-run. Investment was positively related to inflation rate but not significant in the short-run but the relationship was negative and significant in the long-run. The study therefore recommended among others that government should exercise discretion in spending in order to check inflation rate. This can be done by channeling spending on productive activities that will cushion the effect of inflation rate rather than exacerbate it.
\end{abstract}

Keywords: inflation rate, government expenditure, ARDL and Nigeria

\section{Introduction}

The theoretical correlation between government expenditure and inflation has continued to generate series of argument amongst scholars of economics. Governments' primary tasks: Protection (and security) and provision of certain public goods. Protection function consists of the creation of the rule of law and enforcement of property rights. This helps to minimize risks of criminality, protect life and properties, and the nation from external attacks. The provisions of public goods are roads, health, defense, education etc. While some scholars argued that increase in government expenditure on socio- economic and physical infrastructures encourage economic growth like the Keynesians, others strongly disagree with this; the classical economists.

Government needs to spend in order to ensure stability of the economy, stimulate productivity or investment according to the Keynesian view. Government also spends in order to redistribute income between the rich and poor. However some scholars like Adam Smith, J.B Say argued that increasing government expenditure promotes economic growth, instead they assert that higher government expenditure may slow down the overall performance of the economy. For instance, in an attempt to finance rising expenditure, government may increase taxes and/or borrowing which would reduce the amount of disposable income available to individuals.

According to the neoclassical economists increase in government expenditure could result to high inflation outcomes given the full employment assumptions, they believed that increased government spending exacerbate an economic contraction by shifting resources from the private sector, which they consider productive to the public sector which they consider unproductive. Furthermore, in a bid to score cheap popularity and ensure that they continue to remain in power, politicians and government officials sometimes increase expenditure and investment in unproductive projects or in goods that the private sector can produce more efficiently. Thus, the national output growth is seldom slowed due to resource misallocation by government.

Inflation is a consistent rise in the cost of goods and services in an economy over a time period. Inflation affects an economy in positively and negatively. Positive effects includes reducing the real burden of public and private debt, while negative effects of inflation includes an increase in the opportunity cost of holding money, uncertainty 
over future inflation which may discourage investment and savings, and if inflation is rapid enough, there will be shortages of goods as sellers begin hoarding out of concern that prices will increase in the future. The problem created by the rising prices of goods and services leading to a high cost of living has become too difficult for the government to solve today, most economists favor low and steady inflation rate; Low ( as against zero or negative inflation ). Inflation makes economic recessions less severe by enabling the labor market to adjust more quickly in a downturn, and reduces the risk that a liquidity trap prevents monetary policy from stabilizing the economy.

Sachs (2006) argued that in more developed countries, the highly taxed and high social welfare perform better than countries with low taxation and low social welfare. It is on this backdrop that this study tends to examine the relationship that exists between government expenditure and inflation in Nigeria.

In addition, Nigeria's growth in GDP over the years has been accompanied by rising rates of inflation. The growth in GDP has been attributed to increase in oil revenues by government. However, growth in GDP has not translated to structural changes in production. GDP increase has been linked to an increase in the expenditure power of government. The increase in the expenditure power of government tends to crowd out private investment by driving up interest rates which would reduce the profit margin of investors. With the profit margin reduced, the incentive for investment would reduce; productive activities would decrease causing a reduction in output, the reduction in output would lead to a supply constraint causing aggregate demand to be greater than aggregate supply. Much money would be chasing fewer goods, this would lead to an increase in the prices of goods and services, in this situation, inflation is said to occur.

As with other IMF backed program measures were to be taken to reduce government expenditure such measures includes the reduction of the growth of government wage bill, reduction in government subsidies on food, petroleum and petroleum products etc past governments have tried to find solutions to these problems but to no avail, even though inflation is increasing at a decreasing rate its effects still persists everywhere. The effect on the people and the need to find a way out of the predicament has been the major driving force that has led to the study of the cause of inflation in Nigeria - with reference to the public expenditure of the Nigerian government. The objective of this paper is to examine the influence of government expenditure on the rate of inflation (using the consumer price index: CPI in Nigeria).

\section{Literature Review}

Economists from varied school of thoughts have developed thoughts to the study of government expenditure and the rate of inflation in the past. For this purpose of clarity and comprehensive study we shall discuss that of government expenditure only.

\subsection{Theories of Government Expenditure}

The role of a government to economic growth is mostly depicted on through their choices on monetary and fiscal policies. Literature on public expenditure until the past era 1929-30 Great depression, where economies underwent rising public expenditure, Adolph Wagner $(1883,1893)$, Alan Peacock and Jack Wiseman (1961), as well as the classical and Keynesian economists poured light on the nexus of government expenditure. These theories' outlook will be clarified here, supplemented by Musgrave and Rostow's development model.

\subsection{The Classical/ the Keynesian Approach of Public Expenditure}

The classical economists believed that the government intervention brings more harm than good to an economy and that the private sector should carry out most of the activities. Adam Smith wrote in the "wealth of nations" that government should focus on defense against external aggression, keeping internal peace and order, public development work. All other roles besides these were taken as unnecessary by the state and considered as unjust and wasteful. According to the classicists increase in the total amount of money leads to a changes in prices in the same direction propotionately, with the allocation of resources unchanged.

Following the 1929-1930 Great depression the classicists argued that strong trade unions prevented wages flexibility which resulted in high unemployment. The Keynesians on the other hand favored government intervention to correct market failures. In 1936, John Maynard Keynes (1883-1946) "general theory of employment, interest and money" criticized the classical economists to put too much emphasis on the long run. Keynes believed depression needed government intervention as a short term cure. Whereas, the classical economists believed that supply created its own demand, Keynes argued that causation ran the other way- from demand to supply. In Keynes' view, businesses base their productive decisions on the level of expected total spending. Most important, Keynes argued that the full employment may not be possible because the level of total spending in the economy may be insufficient, that the classical economists were incorrect to believe that interest 
rate adjustments and wage/price flexibility would prevent unemployment. According to Keynes, adequate total spending can ensure full employment. if spending is inadequate, unemployment will result.

\subsection{Adolph Wagner's Law of Increasing State Activities}

Wagner's law is named after the German political economist Adolph Wagner (1835-1917) who developed a "law of increasing state activity" after empirical analysis on Western Europe at the end of the $19^{\text {th }}$ century. He argued that government growth is a function of increased industrialization and economic development. Wagner stated that during the industrialization process, as real income per capita of a nation increases, the share of public expenditures in total expenditure increases. The law cited that "the advent of modern industrial society will result in increasing political pressure for social progress and increased allowance for social consideration by industry".

Wagner (1893) came up with three key areas for government to increase her expenditure. Firstly, in the area of industrialization process where public activities will overwhelm private activities, the protective and administrative duties of the state will increase. Secondly, provision of social welfare services; education, hospital, electricity. Thirdly, increased industrialization will bring out technological change and large firms that tend to monopolize. Government will have to offset these effects by providing social and merit goods through budgetary means.

\subsection{The Peacock and Wiseman Theory of Public Expenditure}

Peacock and Wiseman conducted a new study based on Wagner's law. They studied the United Kingdom's public expenditure from 1891 to 1955. It was found out that Wagner's law stood. It was suggested Wagner's theory does not align with experienced public expenditure growth. Peacock and Wiseman choose the political propositions instead of the organic state where it is deemed that government like to spend money, people do not like increasing taxation and the population voting for ever-increasing social services. They further stated that the rise in public expenditure greatly depends on revenue collection over the years, economic development results in substantial revenue to the government; this enabled to increase public expenditure. They stated that increased defense spending was achieved by upward reviews of tax rates and expanded tax structures. There may be differences in thoughts about suitable public spending and taxation limits but these can be narrowed by large scale disturbances, such as major wars, according to Peacock and Wiseman, these disturbances will cause displacement effect, shifting public revenue and public expenditure to new levels.

Peacock and Wiseman saw that period of displacement as reducing barriers that protect local autonomy and increasing the concentration power over public expenditure to the central government. When public expenditure are being centralized, the role of state activities tends to grow larger and larger.

\subsection{Musgrave and Rostow's Development Model}

The economists, Musgrave and the economic historian, Rostow (separately) suggested that the growth of public expenditure might be related to the pattern of economic growth and development in societies. Three stages in the development process could be distinguished:

a) The early development stage where substantial social overhead capital is needed and where private saving is inadequate to finance this necessary expenditure (in this stage, government expenditure must thus be a high proportion of total output);

b) The high phase of sharp growth characterized by large increases in private saving and public investment fall proportionately; and

c) High income societies with increased demand for private goods which need complementary public investment (e.g. the motor car and urbanization)

The increasing need in high income societies for skilled labor lead education to become increasingly an investment good for society as a whole. Increased population movements leads to the development of urban slums, such factors and others leads once again to an increase in public expenditure in relation to total output.

These views are interesting in relation to theories of growth and development but are rather too general to provide much of a guide to recent experience in developed industrial countries.

\subsection{Structure of Government Expenditure in Nigeria}

The structure of Nigeria government expenditure can basically be categorized into capital and recurrent expenditure. Recurrent expenditure is current or consumption expenditure incurred on civil administration, defense forces, public health, wages, salaries, maintenance etc. While capital expenditure are incurred on building durable 
assets like highways, multipurpose dams, irrigation projects, telecommunication, electricity, airports, education etc.

\subsection{Empirical Literature Review}

It is commonly supposed in public and academic discourse that inflation and government are related. With bias to developed and developing countries, there have being theoretical empirical research that attempt to focus on the relationship between inflation and government spending.

Hans \& Mulligan (2002) investigated the relationship between inflation and the size of government. The paper showed that inflation relates significantly to government size when compared in peace and war periods. Also it showed that there is a weak positive peace time series correlation between inflation and the size of government and a negative cross-country correlation of inflation with non-defense spending. It found that a positive relationship exists between a big size of government (government spending) and inflation, that large government causes high inflation rates.

Fischer et al. (2002), using the data set of 94 developing and developed countries from 1960-1995, discovered that the relationship between fiscal deficits and inflation is only strong in high inflation countries during low-inflation episodes.

Atao \& Terrones (2005) used the pooled mean group estimation method to a data set spanning over 107 countries from 1960-2001. It is shown that empirically, deficits have a stronger impact on inflation in developing countries.

Ezirim, Muoghalu, Elike (2008) in their work titled "Inflation versus public expenditure growth" in the US; an empirical investigation using co-integration analysis and granger causality model found that inflation significantly influences public expenditure decisions in the United States of America. Increase in public expenditure increases inflation while a reduction in public expenditure tends to reduce inflationary trend. Thus, as in previous studies, the efficiency of Keynesian's fiscal policy as a veritable tool to combating inflation in the developed country is not falsified. Their work lends credence to the effectiveness of Keynes fiscal policy as an instrument of macroeconomic stabilization.

Mohammed et al. (2009) carried out a study on long-run relationship amongst broad money supply, inflation, government expenditure and economic growth Pakistan. The paper adopted the Johnson co-integration and granger causality test to find out long-run association and causality. The paper showed a negative relationship between public expenditure and inflation. They attempted to explain that most of public expenditure is non-development and inflation is due to adverse supply stock (cost push inflation) in Pakistan.

Magazimo (2011) carried out a study on the link between public expenditure and inflation for the Mediterranean countries; 1970-2009. It was found that a long-run relationship between the growth of public expenditure and the rate of inflation for some countries. In addition, Granger causality tests results revealed a short-run evidence of a directional and bi-directional relationship from expenditure to inflation rate for all countries.

Nwosa \& Amassoma (2012) reported the presence of a long-run relationship among the variables used in carrying out the study. Its findings showed that the existence of a bi-directional causality between government expenses and the growth of the economy in the short-run/ long-run while a unidirectional causality was observed in the short-run.

This result shows that Nigeria's inflation rate has both government spending and economic growth as contributing factors. Based on these findings, they recommend that government should implement policies that would moderate government spending in order to reduce inflation rate. To complement for the slowed economic growth that stems from reduced government spending, moderated lending rates should be administered to boost private investors' confidence in the Nigerian economy.

Jayaraman \& Chen (2013) understudied the relationship between budget deficits and inflation in the four pacific island countries (PICs). It was accomplished by undertaking an empirical study of relationship between budget deficits in the four PICS through a panel of econometrics analysis. The framework used was multivariant, as its effect on broad money growth is most durable and strongest on the short-run.

Musa \& Asare (2013) carried out a research on the long/ short run relationship of monetary and fiscal policies on economic growth in Nigeria. A Vector Error Correction Mechanism (VECM) technique was adopted for analysis. Findings revealed that monetary policy enact greater impact on the economic growth but the effect of fiscal policy is lesser, specifically when there is a decrease in inflation.

Olayungbo (2013) carried out a study on government spending and inflation in Nigeria; 1970-2010. The asymmetry causality test unveiled that a one-directional causality exists from negative government spending 
changes to positive inflation changes in the VAR model. This implies an inflationary pressure in Nigeria is state dependent, that is high inflation is caused by Low/contractionary government spending.

All these studies investigated the influence of government expenditure at difference time on the inflation rate of various economies. The paper aims is to try empirically, the relative effectiveness of government expenditure on inflation using the consumer price index from 1980-2019 extending the work of Olayungbo which only covers 1970-2010 to capture the real effect of government expenditure on inflation in Nigeria with the application of the Ordinary Least Square (OLS) technique, filling the gap created by Olayungbo's work.

\section{Technique of Data Analysis}

\subsection{The Autoregressive Distributed Lag (ARDL)}

However, in order to make the study robust, the Auto-regressive Distributed Lag (ADL) was adopted in other to estimate the effect of government spending on inflation. This was important so as to determine the impacts of the previous values of government expenditure, the past and present values of money supply, gross domestic product, population, investment, and exchange rate. The short run dynamics of the Auto-regressive Distributed Lag model is specified thus:

$$
\begin{aligned}
\text { InCPI }_{t}=\beta_{0}+ & \beta_{1} G E X_{t}+\beta_{2} G E X_{t-k}+\beta_{3} M S_{t}+\beta_{4} M S_{t-k}+\beta_{5} G D P_{t}+\beta_{6} G D P_{t-k}+\beta_{7} E X R_{t} \\
& +\beta_{8} E X R_{t-k}+\beta_{9} P O P_{t}+\beta_{10} P O P_{t-k}+\beta_{11} G F C F_{t}+\beta_{12} G F C F_{t-k}+E C M_{t-k}+U_{t}
\end{aligned}
$$

The long run form of the Auto-regressive Distributed Lag model is specified thus:

$$
I_{n C P I}=\beta_{0}+\beta_{1} G E X_{t}+\beta_{2} M S_{t}+\beta_{3} G D P_{t}+\beta_{4} E X R_{t}+\beta_{5} P O P_{t}+\beta_{6} G F C F_{t}+U_{t}
$$

\subsection{F-Bounds Cointegration Test}

The F-bounds test is a technique of the Auto-regressive Distributed Lag (ADL) that ascertained if variables are cointegrated. This was adopted to ascertain the long run relationship between public infrastructure and industry value added.

Autocorrelation Test: The Durbin Watson test was used to test for the presence of autocorrelation in the model.

Heteroscedasticity Test: The Breusch-Godfrey heteroscedasticity test was used to ascertain if the error variance of each observation is constant or not.

Normality Test: The Jacque-bera test was used to test if the variables in the model adhere to normal distribution.

\section{Data Analysis}

\subsection{Trend Analysis}

The trend analyses bother on the trends in inflation rate (consumer prices) and government expenditure during the period under review. The trends in inflation rate (consumer prices) and government expenditure are displayed in figures $1 \& 2$.

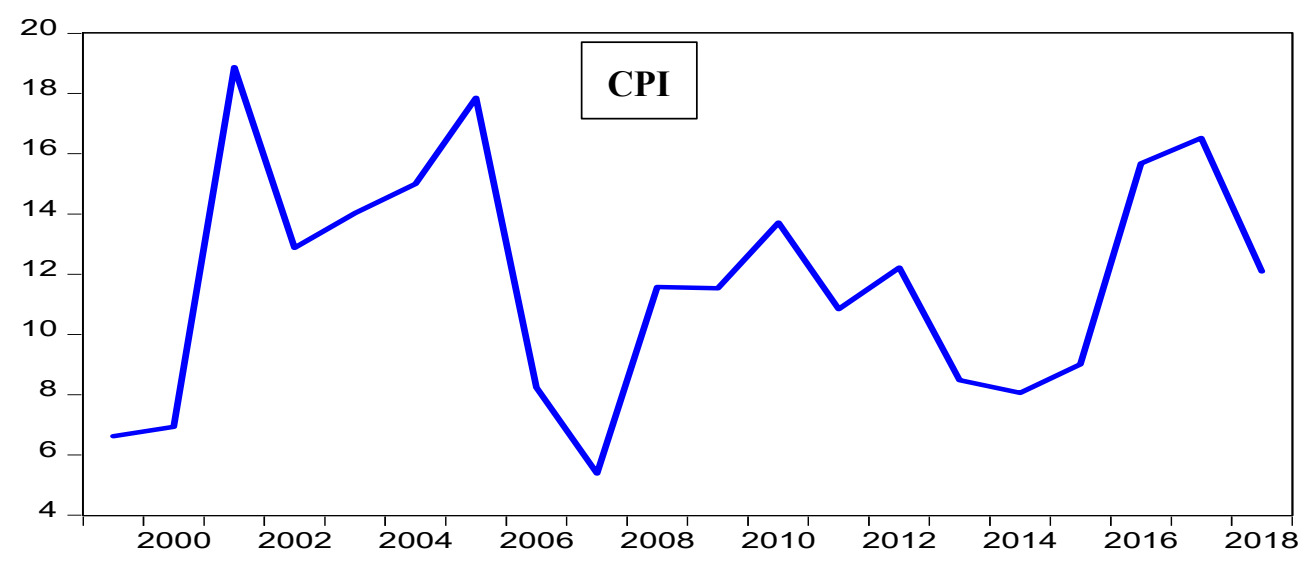

Figure 1. Shows the inflation rate (consumer prices) from 1999 to 2019

The inflation rate in terms of consumer prices showed various fluctuations with peak of $72.8 \%$ in 1995 . It showed decreasing tends since the year 1995, and has since fluctuated in an upward-downward pattern till 2019. 


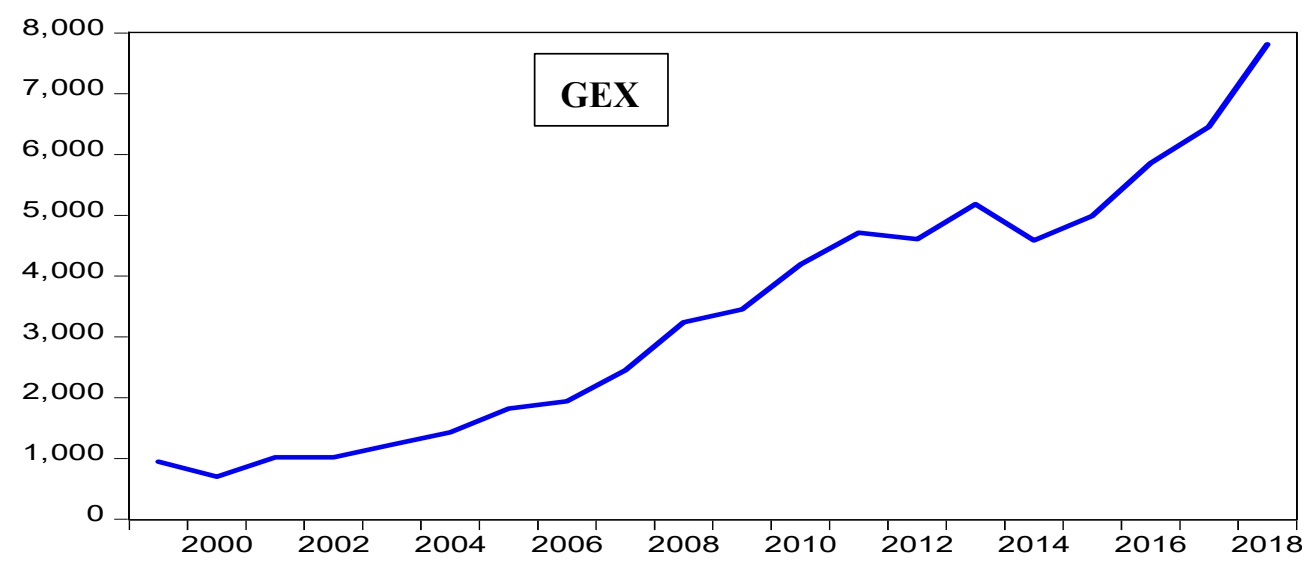

Figure 2. Shows the trend in government expenditure from 1999 to 2019

The trend in government expenditure shows upward fluctuations. It increased from 947.69 billion naira in 1999 to 701.5 billion naira in 2000. It further increased to 4194.577 billion naira in 2010 and peaked at 7813.741 billion naira in 2019.

All the variables showed stationary trends at levels and first difference. It is necessary to conduct diagnostic tests to ensure that the Autoregressive Distributed Lag model is fit for interpretation and policy purposes. Hence Table 2 shows the various diagnostics tests.

Table 2. Diagnostics Test for Auto-regressive Distributed Lag Model

\begin{tabular}{|c|c|c|}
\hline \multicolumn{2}{|l|}{ Diagnostics tests } & ADL Model \\
\hline \multicolumn{2}{|c|}{ Autocorrelation (Durbin Watson) } & 1.64 \\
\hline & F-statistics & 3.6735 \\
\hline & Prob. F-statistics & 0.0467 \\
\hline \multirow{3}{*}{ Heteroscedasticity (White) } & Obs*R-squared & 17.2593 \\
\hline & Prob. Chi-Square & 0.1401 \\
\hline & JB Statistic & 0.5205 \\
\hline \multirow[t]{3}{*}{ Normality (Jarque-Bera) } & Probability & 0.7709 \\
\hline & F-statistics & 20.83 \\
\hline & Lower Bounds (5\%) & 2.27 \\
\hline \multirow{2}{*}{\multicolumn{2}{|c|}{$\begin{array}{l}\text { F-Bounds Test } \\
\text { Adjusted R-Squared }\end{array}$}} & 3.28 \\
\hline & & 0.9609 \\
\hline \multirow{2}{*}{\multicolumn{2}{|c|}{$\begin{array}{l}\text { F-statistics } \\
\text { Prob(F-statistics) }\end{array}$}} & 13.3978 \\
\hline & & 0.0011 \\
\hline
\end{tabular}

Source: E-views 9.0

Table 2 shows the diagnostics tests for the Auto-regressive Distributed Lag model. The autocorrelation value of 1.64 implies there is no serial correlation in the error in the ADL model. The observed r-squared of the White's heteroscdasticity test shows that the variance is homoscedastic. Also, the Jarque-bera value of the normality test shows that the ADL model follows the normal distribution. The F statistics of the F-bounds test is 20.83 . The F statistics of the F-bounds tests is greater than the lower and upper bounds at the 5\%. These show that the variables in the ADL model have long run relationship. The adjusted coefficient of determination is 0.9609 . This implies that the $96.1 \%$ variation in industry output is explained by the variations in the independent variables. The $p$ value of the F-statistics shows that the ADL model was significant at the 5\% level of significance.

Having analysed the diagnostics tests, it is imperative to analyse the short and long run relationship of government expenditure and inflation rate using the ARDL technique. 
Table 3. ARDL Regression Results

\begin{tabular}{lllll}
\hline Short Run ARDL Regression Results & & & \\
\hline Variable & Coefficient & Std. Error & t-Statistic & Prob. \\
C & 473.1149 & 90.54203 & 5.225362 & 0.0008 \\
DLOG(CPI(-1)) & -1.617508 & 0.162477 & -9.955297 & 0.0000 \\
DLOG(GEX) & 0.673864 & 0.129848 & 5.189618 & 0.0013 \\
DLOG(MS) & -1.749544 & 0.134397 & -13.01769 & 0.0000 \\
DLOG(GDP) & -19.37647 & 1.636079 & -11.84324 & 0.0000 \\
DLOG(EXR) & 2.582329 & 0.179273 & 14.40443 & 0.0000 \\
DLOG(POPG) & -3.858422 & 3.822876 & -1.009298 & 0.3464 \\
DLOG(GFCF) & -1.583251 & 0.141001 & -11.22866 & 0.0000 \\
CointEq(-1)* & -1.617508 & 0.088597 & -18.25700 & 0.0000 \\
\hline Long Run ARDL Regression Results & & & \\
\hline Variable & Coefficient & Std. Error & t-Statistic & Prob. \\
\hline LOG(GEX) & 0.048718 & 0.342405 & 0.142282 & 0.8909 \\
LOG(MS) & -0.671238 & 0.255104 & -2.631235 & 0.0339 \\
LOG(GDP) & -0.239372 & 0.524828 & -0.456097 & 0.6621 \\
LOG(EXR) & 1.943715 & 0.299799 & 6.483404 & 0.0003 \\
LOG(POPG) & 19.88326 & 6.261425 & 3.175517 & 0.0156 \\
LOG(GFCF) & -2.078117 & 0.350684 & -5.925898 & 0.0006 \\
C & 62.63834 & 11.85422 & 5.284056 & 0.0011 \\
\hline
\end{tabular}

Source: E-views 9.0

The short run results show how government expenditure along with some control variables affects inflation rate in Nigeria during the period under study. The Error Correction coefficient of -1.617508 shows the adjustment speed to equilibrium of the present and past values of independent variables on the dependent variable. The $5 \% \mathrm{ECM}$ coefficient was found to be significant.

The coefficient of GEX is 0.673864 . This indicates that the relationship between inflation and government expenditure is positive in the short run. This supports economic theory that increase in government expenditure increases employment, and when more people are employed, their purchasing capacity increases. Their increase in demand increases the prices of products. However, the relationship was significant at the $5 \%$ level. It can be noted that government expenditures of previous years affected inflation rate in a positive way and it's significant. Hence, previous levels of government spending have supported the continuous rise of products in the short run. However, the long-run analysis shows that government expenditure positively affected inflation but was not significant at the $5 \%$ level.

Also, money supply affected the inflation negatively with a coefficient of -1.749544 . However, the relationship was not significant at the $5 \%$ level. Similar to the past relationss between government and inflation, previous levels of money supply have established that inflation rate is due to monetary factors. Previous money supply levels have altered inflation rate in a positive way and it is significant. Moreover, results of the long-run indicts that money supply affected inflation rate favourably and it is significant at the $5 \%$ level. This shows that government spending may not be responsible for the increase in inflation; rather inflation rate is caused by money supply.

Other variables that represented other sectors were included in the model. These variables are Gross Domestic Product (GDP), exchange rate, investment, and population. The Gross Domestic Product was negatively related to inflation rate in both the short-run and long-run. The rate in which the naira exchanges the dollars affected inflation rate positively and significantly in both the short run and the long run. The increasing demands of the population affected inflation rate positively and significantly in the long-run. Investment has an opposing relationship with the inflation rate and relevant in both short-run and long-run.

\section{Conclusion}

Nigeria's 1999 to 2019 inflation response due to government spending was dissected in this paper. The study used the robust Autoregressive distributed lag model to estimate the model. Trend analysis revealed that government expenditure trended upwards for the studied period. The study found that government expenditure has positive and significant effect on inflation rate in the short-run. However, the positive effect on inflation was no longer potent 
in the long-run. Other variables affected inflation rate during the period under study. Based on the findings, it is recommended that:

1) Government should exercise discretion in spending in order to check inflation rate. This can be done by channeling spending on productive activities that will cushion the effect of inflation rate rather than exacerbate it.

2) The apex monetary institution, the Central Bank of Nigeria (CBN) should support the government since their activities also alter inflation rate significantly.

\section{References}

Agiobenebo, T. J. (1996). Introductory Macroeconomics fort heory and Applications. Markowtiz Center for Research and Development Port Harcourt.

Amassoma, D., \& Nwosa, P. (2011) components of Government Spending and Economic Growth in Nigeria: an error correction modeling. Journal of Economics and sustainable Development, 2(4).

Asogu, J. O. (1991). An Economics analysis of the nature and causes of inflation in Nigeria" CBN Economics and Financial Review.

Central Bank of Nigeria, Annual Report. (2014, 2015).

Cookey, A. E. (1998). Research Methods, for Business and Economics Students. Abbot Books Ltd, Onitsha Nigeria.

Ezirim, C. B., Muoghalu, M. I., \& Elike, U., \& Amuzie, A. E. (2008). Public Expenditure Growth, Inflation and Cointegration. North America Journal of Finance, 1(1).

Fischer, S., Ratna, S., \& Carlos, V. (2002) Modern Hyper and High Inflations. Journal of Economic Literature, 40, 837-880. https://doi.org/10.1257/jel.40.3.837

Gbanador, C. A. (2007). Modern MacroEconomics. Pearl Publisher, Port Harcourt.

Gbosi, A. N. (2002). Contemporary Issues in Nigeria's Public Finance and Fiscal Policy. Pack publishers, Abakaliki.

Gbosi, A. N. (2003). Fundamentals of International Economics and Finance. Pack Publishers, Abakaliki.

Kalu, I. E. (2011). Statistics, Basic Concepts and Methods. TosCom Integrated Services, Port Harcourt.

Kanu, S. I., Ozurumba, B. A., \& Ihemeje, J. C. (2014). Examining the Relationship between Federal Government of Nigeria's Revenue and Expenditure Profiles.

Magazzino, C. (2010). The Nexus between Public Expenditure and Inflation in the Mediterranean Countries, School of Political Sciences, Roma Tre University, Italian Society of Economist (S.I.E), Royal Economic System (RES).

Musa, Y., \& Asare, K. (2013). Effect of Monetary-Fiscal Policies interaction on Price ans Output Growth in Nigeria. CBN journal of applied statistics, 4(1).

Nye Tom-Ekine, J. C. (2014). Macroeconomics, Public Policy and International Finance. Dominus Press, Port Harcourt.

Okowa, W. J. (1999). Macroeconomics for Universities. Pam Unique Publishing, Port Harcourt.

Olaiya, S. A., Nwosa, P. I., \& Amassoma, D. (2012). A Trivariate Causality Test Among Economic Growth, Government Expenditure and Inflation Rate: Evidence from Nigeria. Research Journal of Social and Management Science (Abraka), 5(2), 9-19.

Olayungo, D. O. (2013). Government Spending and Inflation in Nigeria: An Asymmetry Causality Test. International Journal of Humanities and Management Sciences (IJHMS), 1(4).

Onuchuku, O. (1998). Inflation and stabilization policy measures in Nigeria. Emhahi Printing and Publishing Co Choba, Port Harcourt.

Onuchuku, O., \& Adoghor, G. (1999) Econometrics: An Introduction to Ordinary Least Squares Regression Analysis. Springfield Publishers, Owerri Nigeria.

\section{Copyrights}

Copyright for this article is retained by the author(s), with first publication rights granted to the journal. 
This is an open-access article distributed under the terms and conditions of the Creative Commons Attribution license (http://creativecommons.org/licenses/by/4.0/). 